\title{
Students' Perception of Teachers' Characteristics and Their Attitude towards Mathematics in Oron Education Zone, Nigeria
}

\author{
Etuk N. Etuk ${ }^{1}$, Maria E. Afangideh ${ }^{1} \&$ Asukwo O. Uya ${ }^{1}$ \\ ${ }^{1}$ Department of Curriculum Studies, Educational management and planning, University of Uyo, Uyo Akwa \\ Ibom State, Nigeria \\ Correspondence: Etuk N. Etuk, Department of Curriculum Studies, Educational Management and Planning, \\ University of Uyo, Uyo. Akwa Ibom State, Nigeria. Tel: 234-803-099-5288. E-mail: e_etuk@yahoo.com
}

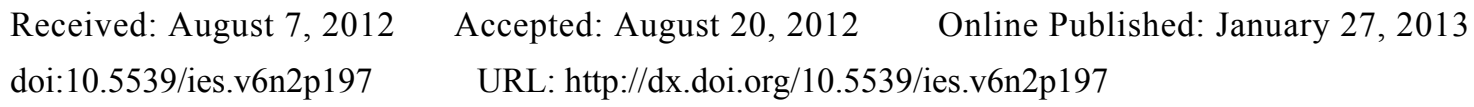

\begin{abstract}
The study sought to find out the relationship between how students perceive their teachers' in respect of knowledge of Mathematics content, communication ability, use of appropriate teaching strategies and teachers' classroom management skills and students' attitude towards mathematics. The population of the study comprised all the second year students in senior secondary schools in Oron Education Zone. The study sample consisted of 640 students selected through cluster and simple random sampling techniques. Two instruments - Students' Perception of Teacher Characteristics Questionnaire (SPTCQ) and Students' Attitude towards Mathematics Questionnaire (SATMQ) were developed and administered on the respondents. A trial test of 50 students using split-half reliability test was carried out which yielded reliability coefficients of 0.86 and 0.94 for SPTCQ and SATMQ respectively. Pearson Product Moment Correlation and t-statistics were used to answer the research questions and test the hypotheses respectively. Findings show that the way students' perceive their teachers' in terms of knowledge of mathematics contents, communication ability, teaching methods and classroom management skills has a significant relationship with students' attitude towards mathematics. When the students' perception of their teachers' characteristics is low, students' attitude towards mathematics tends to be negative.
\end{abstract}

Keywords: perception, teachers' characteristics, students' attitude

\section{Introduction}

The importance of teacher characteristics in realizing educational goals and objectives in any educational system cannot be over emphasized. Teacher characteristics are the instructional behaviours exhibited by the teacher towards goal attainment. These characteristics are the combination of peculiar qualities, traits, mental or moral nature/strength and status that make one person or group different from another. Successful teachers' characteristics are those that have been found by empirical researches to be related to improved achievement by students in the cognitive, affective or psychomotor outcomes of education (Offorma, 1994).

The bedrock of educational system lies on a core of devoted, knowledgeable, competent and well-trained teachers. Groton (1983) rightly pointed out that if a person is to be successful in his chosen career, that individual also needs a set of ethical beliefs or standards for guidance or direction in the appropriate use of competences. A competent teacher seeks to know his learners' behaviour in teaching, must perceive the individual learner as a whole since he has affective, cognitive and psychomotor talents.

Also, students' participation in the instructional process is critical and their perception presents methodological challenges. The knowledge of the way the students think and perceive can aid the teacher to reflect upon and adjust his teaching strategies to enhance students' understanding and achievement. Allport (1968) described perception as the way people judge others with whom they are in contact. A persons' attitude to an idea or object determines what the person thinks, feels and how the person would like to behave towards that idea or objects. Schunk (1996) defined attitude as internal beliefs that influence personal actions which is learned through one's experience. This has to do with a disposition to act or react in a particular way as the individual responds to a situation (Amoo \& Rahman, 2004). Thus, the students' perception of the teachers' characteristics could influence their attitude toward mathematics or any other school subject. Students more often than not judge their teachers in such areas as the teachers' knowledge of the subject matter, communication ability, the choice of appropriate 
teaching method and the general classroom management skills. A teacher who is rated high on these indices in the perception of the students is likely to enjoy the confidence, respect and admiration of his students.

\subsection{Knowledge of Subject Matter}

Fennema and Frank (1992) agreed that teacher's knowledge of the subject matter is an indicator of teachers' teaching effectiveness. Eggen and Kauchak in Adediwura and Tayo (2007) sub-divided teachers' knowledge of subject matter into: knowledge of content, pedagogical content knowledge and general pedagogical knowledge. Ball and Bass (2000) had earlier explained that knowledge of mathematics itself (knowledge of subject matter) should go further than the specific content of the discipline to the knowledge of how to teach, present mathematical concepts and that of selection and use of instructional media and resources. Muijs and Reynolds (2002) posited that teaching effectiveness of the teacher is hampered if he/she is not versed in the contents to be taught.

A teacher who has a deep understanding of the concept to be taught is more likely to use unambiguous language; his/her presentation is likely to be more coherent and he/she would offer clearer explanation than those with a weaker background, (Uya, 2011). Huckstep, Rowland, and Thwaites (2003) in their finding on importance of mathematics teachers' knowledge of subject contents, affirm that effective teaching that can lead to better achievement by the students and provide a positive attitude depends on teachers' confidence and in-depth knowledge of the subject matter.

\subsection{Communication Ability}

No subject matter can be learnt properly without communication, the use of its appropriate terms facilitates the understanding of whatever is being learnt. Communication may be used to mean the transfer, transmission or exchange of ideas, knowledge, beliefs, attitudes or emotion from one person or group of persons to another (Esu, 2004). Ajibade and Ehindero (2000) opined that if there is any act germane to effective teaching it is that of communicating. Teachers should strive to make their presentation as unambiguous, coherent and logical as possible. Eggen and Kauchak (2001) underlined the basic aspects of effective communication to include precise terminology, connected discourse, transition signals and emphasis. Afangideh (2001) reported that the purpose of communication in the teaching-learning process is to effect change, to produce a desired response; or to influence action contributing to the welfare of the school system. Afangideh (2001) further highlighted four dimensional objectives of communication as: to inform, to stimulate, to persuade and to remind. Uya (2011) asserted that the effectiveness of any educational system depends to a large extent on the effectiveness of the communication system being adopted. And that the teacher has the capability to change the attitude of another person if there is trustworthiness, belief and validity of what he says. To a large extent the effectiveness of any classroom interaction is determined by the competency of the teacher to initiate and sustain communication between and among his/her students. (Ahmad,2009).

\subsection{Teaching Method}

The use of appropriate teaching method incorporates an ordered way of accomplishing an end or performing a task. Adediwura and Tayo (2007), described methods as patterns to be followed in teaching/learning process to drive home a point. Whether in formal or informal education, teaching method effectiveness makes for retention of learnt concepts. The extent to which an instructional procedure is potent depends greatly upon its effective use by the instructor and the impression it leaves on the learner, which is usually evident in their attitude as well as performance (Obanya, 1984). Umoren (2001) in a research on methods of teaching suggested that the ability of the teacher to impart knowledge so depends greatly on the method he applies during the teaching learning process. Where the method is defective, the students stand to lose as they hardly benefit from lessons.

According to Uya (2008), for teacher to be able to ensure order and enhance classroom learning, they have to possess necessary pedagogical skills which have to be systematic and methodical. They have to explore and make good use of their knowledge of instructional skills/strategies, whether the method adopted falls within the spectrum of mass or individualized instructional methods (Umoh, 2005). Esu (2003) opined that teaching, by its nature requires a variety of methods to facilitate teaching/learning in the class and to develop the child's knowledge and understanding to the maximum.

\subsection{Classroom Management Skills}

Classroom management is the process of leading, directing, ordering or restraining of students in a class in a way that will lead to effective learning. Byrne, Hattie and Fraser (2001) observed that students will perform best in a controlled atmosphere that is conducive to academic and social needs of the students. The atmosphere in the classroom needs to be relaxed, free from threats and anxiety, non-competitive and thought provoking to allow 
students participate and enjoy the lesson. Under such atmosphere the students' interest in and attitude towards the subject taught could be enhanced. Isangedighi (2007) stated that disciplined behaviour in the class is the child's ability to exercise self-control under a given classroom condition. Udofot (1995) explained that while the classroom serves as a theatre stage for learning, the prevailing management and discipline are strong determinants of successful learning and commensurate outputs. Thus the goal of effective classroom management is to have students display appropriate behaviour during class activities in order to enhance the teaching and learning process that can lead to the attainment of set objectives.

Teacher's characteristics in instructional delivery are therefore a measure of the teacher's ability to apply his professional skills in a teaching/learning situation. The question in this study could then be asked: to what extent do teachers' characteristics influence students' attitude towards mathematics.

\section{Problem of the Study}

Students' impression is that mathematics is difficult by its very nature, and that mathematics is highly structured and so abstract that it requires special intellectual talents. Thus, students see the subject as something esoteric that is to be feared (Nworgu, 1990). The consequences of students' negative attitude towards mathematics could be the persistent poor performance in mathematics in the West African Examination Council (WAEC) examinations, the National Examination Council (NECO) examinations and the General Certificate in Education (GCE) examinations in recent years in Nigeria and students reluctance in studying mathematics related courses. The negative attitude and poor performance produced has continued to subject teachers to criticisms of poor characteristics and lack of necessary professional qualification. This study sought to investigate the perception of students with respect to their teachers' characteristics- knowledge of mathematics contents, communication ability, use of appropriate teaching methods and classroom management's skills- as they influence students' attitude towards mathematics.

\subsection{Research Questions}

The study sought to answer the following questions:

1) What is the relationship between how students perceive their teachers with respect to teachers' knowledge of mathematics contents and their attitude towards mathematics?

2) How does students' perception of their teachers' communication ability relate with students' attitude towards mathematics?

3) What is the relationship between how students' perceive their teachers' ability to use appropriate instructional method and their attitude towards mathematics?

4) What is the relationship between students' perception of their teachers' classroom management skills and students' attitude towards mathematics?

\subsection{Hypotheses}

The research questions were translated into the corresponding hypotheses to guide the study. These are:

1) How students perceive their mathematics teachers' knowledge of mathematics contents does not relate significantly with their attitude towards mathematics.

2) Students perception of their mathematics teachers' communication ability does not relate significantly with their attitude towards mathematics.

3) Students perception of their mathematics teachers' ability to use appropriate instructional method does not relate significantly with their attitude towards mathematics.

4) How students perceive their mathematics teachers' classroom management skills does not significantly relate with their attitude towards mathematics.

\subsection{The study}

The expost facto correlational design was adopted for the study. The population consisted of all the 3411 senior secondary school two (SS11) students in the 19 Public secondary schools in Oron Education Zone of Akwa Ibom State during the 2010/2011 academic session. The cluster and simple random sampling techniques were adopted in drawing the sample of the study which stood at 640 .

\subsection{Instrumentation}

Two research instruments were developed and used for the study. These were Students' Perception of Teacher's Characteristics Questionnaire (SPTCQ) and Students' Attitude towards Mathematics Questionnaire (SATMQ). 
The SPTCQ consisted of 36 items on teachers' characteristics and the SATMQ contained 18 items on students' attitudes.

\subsubsection{Validation and Reliability of the Instruments}

The copies of the questionnaire were critiqued for face validity by asking experts in curriculum studies and educational evaluation departments to review the items. This led to the correction of some grammatical expressions, re-structuring of some items and outright cancellations of others. Fifty (50) students were drawn outside the sampled area, and a split-half reliability test used to determine the reliability coefficient of the instruments SPTQ and SATMQ. The scores from the two sets were correlated using Pearson Product Moment Correlation Analysis and corrected with Spearman - Brown Prophecy formula. This gave the reliability coefficients of 0.86 and 0.94 for SPTCQ and SATMQ respectively, indicating that the instruments were good enough for the study.

\subsubsection{Administration of the Instruments and Scoring}

The questionnaire was the main instrument used for data collection. These instruments were administered personally by the researchers in each of the sampled schools with the help of some teachers as assigned by the school authority after permission was granted. The respondents were advised to be honest in their response as information obtained would be treated with all amount of confidentiality and used only as data for the research work. The items in the questionnaire were sorted out according to the variables they were designed to measure. Positive items were rated from strongly agree (4), agree (3), disagree (2), and strongly disagree (1), while negative items were scored in the reverse order of strongly disagree (4), disagree (3), agree (2) and strongly agree (1). Data collected were analysed using Pearson Product Moment Correlation Coefficient (r) for the research questions and (r) subjected to t-statistics for the hypotheses to determine the level of influence of teacher characteristics on students' attitudes.

\section{Results}

\subsection{Research Question 1 and Hypothesis 1}

Table 1. Mean value, Pearson Product Moment Correlation Analysis and t-statistics of how students perceive their teachers knowledge of mathematics contents and their attitude towards mathematics

\begin{tabular}{llllll}
\hline \multicolumn{1}{c}{ Variables } & $\sum \mathrm{x}$ & $\sum \mathrm{x}^{2}$ & $\sum \mathrm{xy}$ & $\mathrm{r}$ & $\mathrm{t}$ \\
& $\sum \mathrm{y}$ & $\sum \mathrm{y}^{2}$ & & & \\
\hline Perception of students about teachers' & 9501 & 144485 & & & \\
Knowledge of mathematics contents(x) & $(2.47)$ & & 434703 & $0.96^{*}$ & 85.73 \\
Students' Attitude (y) & 28700 & 1310553 & & & \\
& & $(2.49)$ & & & \\
& & & & & \\
\end{tabular}

*Significant at 0.05 alpha level; *High relationship, Average mean= 2.50; df $=638 ; \mathrm{r}$-value $=0.08$; $\mathrm{t}$-value $=1.96 ; \mathrm{N}=640$

Table 1 shows that the way students perceive their teachers' knowledge of mathematics content is high and relates positively with their attitude towards mathematics in Oron Education Zone ( $\mathrm{r}=0.96)$. Also, the mean value for teachers' knowledge of the subject matter and students' attitude are 2.47 and 2.49 respectively. Comparatively, these scores fall below the average mean of 2.50. The result indicates a low student's perception of their teachers' knowledge of mathematics contents and a correspondingly negative attitude of students towards mathematics. Table 1 further shows that the calculated $r$-value $(0.96)$ is higher that the table value of $r$ $(0.08)$ at 95 percent confidence level. Also the calculated t-value of 85.73 is higher than the table value of 1.96 indicating that the null hypothesis that had predicated no significant relationship between the way students perceive their mathematics teachers' knowledge of mathematics contents and their attitude towards mathematics is rejected. This shows that the alternate hypothesis is retained that the way students perceive their mathematics teachers' knowledge of mathematics contents relates significantly with their attitude towards mathematics. 


\subsection{Research Question 2 and Research Hypothesis 2}

Table 2. Mean Value, Pearson Product Moment Correlation Analysis and t-statistics of the way students perceive their mathematics teachers' communication ability and their attitude towards mathematics

\begin{tabular}{llllll}
\hline \multicolumn{1}{c}{ Variables } & $\sum \mathrm{x}$ & $\sum \mathrm{x}^{2}$ & $\sum \mathrm{xy}$ & $\mathrm{r}$ & $\mathrm{t}$ \\
& $\sum \mathrm{y}$ & $\sum \mathrm{y}^{2}$ & & & \\
\hline Perception of students about & 8330 & 144623 & & & \\
Teachers' Communication Ability (X) & $(2.16)$ & & 400013 & $0.91 *$ & $55.74^{*}$ \\
Students' Attitude (y) & 28700 & 1310553 & & & \\
& $(2.49)$ & & & & \\
& & & & & \\
\end{tabular}

*Significant at 0.05 alpha level; *High relationship, Average mean $=2.50 ; \mathrm{df}=638 ; \mathrm{r}$-value $=0.08$; t- value $=1.96 ; \mathrm{N}=640$

Table 2 shows a high and positive relationship between teachers' communication ability and students' attitude towards mathematics (0.91). Also, the mean value of how students perceive their mathematics teachers' communication ability and students' attitude are 2.16 and 2.49 respectively. Comparatively these scores fall below the average mean of 2.50. The result shows that students' perception of teachers' communication ability is low and correspondingly students' attitude towards mathematics is negative.

Analysis reveals in Table 2 that the computed r-value (0.91) is higher than the table value of $\mathrm{r}(0.08)$ at 95 percent level of confidence with 638 degrees of freedom. Also, calculated t-value (55.74) is higher than the table value of $\mathrm{t}$ (1.96) indicating that the stated hypothesis that had speculated that the way students perceive their mathematics teachers' communication ability does not relate significantly with their attitudes towards mathematics is rejected. This shows that the alternate hypothesis is retained, that students' perception of their mathematics teachers' communication ability relates significantly with their attitude towards mathematics.

3.3 Research Question 3 and Research Hypothesis 3

Table 3. Mean value, Pearson Product Moment Correlation Analysis and t-statistics of how students perceive their mathematics teachers ability to use appropriate instructional method and their attitude towards mathematics

\begin{tabular}{llllll}
\hline \multicolumn{1}{c}{ Variables } & $\sum \mathrm{x}$ & $\sum \mathrm{x}^{2}$ & $\sum \mathrm{xy}$ & $\mathrm{r}$ & $\mathrm{t}$ \\
& $\sum \mathrm{y}$ & $\sum \mathrm{y}^{2}$ & & & \\
\hline Perception of students about Teachers' & 8190 & 115221 & & & \\
use of appropriate instructional method & $(2.13)$ & & 381258 & $0.89 *$ & $49.05^{*}$ \\
Students' Attitude (y) & 28700 & 1310553 & & & \\
& $(2.49)$ & & & &
\end{tabular}

*Significant at 0.05 alpha level; *High Relationship, Average mean $=2.50 ; \mathrm{df}=638 ; \mathrm{r}$-value $=0.08$; t-value $=1.96 ; \mathrm{N}=640$

Table 3 shows that student's perception of their teachers' ability to use appropriate instructional method relates positively with their attitude towards mathematics (0.89). Also, the mean value for teacher's use of appropriate teaching method and students' attitude are 2.13 and 2.49 respectively. These scores fall below the average mean of 2.50. The result shows that the students' perception of their teachers' use of appropriate instructional methods is low and correspondingly students' attitude towards mathematics is negative. Table 3 further shows that the calculated t-value of 49.05 is higher than the table t-value (1.96). Therefore, the hypothesis that postulated no significant relationship between teachers' use of appropriate teaching methods and students' attitude is rejected. Thus, the alternate hypothesis that the way students perceive their teachers ability to use appropriate instructional methods relates significantly with their attitude towards mathematics is therefore retained. 


\subsection{Research Question 4 and Hypothesis 4}

Table 4. Mean value, Pearson Product Moment Correlation Analysis and t-statistics of the way students perceive their teachers' classroom management skills and their attitude towards mathematics.

\begin{tabular}{lllllll}
\hline \multicolumn{1}{c}{ Variables } & $\sum \mathrm{x}$ & $\begin{array}{l}\sum \mathrm{x}^{2} \\
\sum \mathrm{y}^{2}\end{array}$ & & $\sum \mathrm{xy}$ & $\mathrm{r}$ & $\mathrm{t}$ \\
& $\sum \mathrm{y}$ & & & & \\
\hline Perception of students about Teachers' & 8332 & 131312 & & & \\
Classroom Management skills(x) & $(2.43)$ & & 421513 & $0.89^{*}$ & $49.05^{*}$ \\
Students' Attitude (y) & 28700 & 1310553 & & &
\end{tabular}

*Significant at 0.05 alpha level; *High Relationship, Average mean $=2.50 ; \mathrm{df}=638 ; \mathrm{r}$-value $=0.08$; $\mathrm{t}$-value $=1.96 ; \mathrm{N}=640$

Table 4 shows that the way students perceive their teachers skills in classroom management relates positively with their attitude towards mathematics (0.89). Also, the mean value for teacher's classroom management skills and students' attitude are 2.43 and 2.49 respectively. These scores fall below the average mean of 2.50 . The result shows that the way students think of or perceive their teachers' skills in classroom management is low and correspondingly their attitude towards mathematics is negative.

Furthermore, Table 4 indicates that the r-cal of 0.89 is higher than the table value of $\mathrm{r}(0.08)$ at 0.05 alpha level with 638 degrees of freedom. Also, the calculated $t$-value (49.05) is higher than the table value of $t(1.96)$ indicating that the hypothesis that there would be no significant relationship between the way students perceive their teachers' skills in classroom management and their attitude towards mathematics is rejected. This shows that the alternate hypothesis is retained, that there exist a significant relationship between the way students perceive their teachers' skills in classroom management and their attitude towards mathematics.

\section{Discussion of the Findings}

The result of the data analysis indicates that the way students perceive their mathematics teachers' knowledge of mathematics contents relate significantly with students attitude towards mathematics in secondary schools. This finding is supported by findings of an earlier study by Ajibade and Ehindero (2002) who reported that $98 \%$ of students totally depend on the knowledge of the contents of the subject which is possessed by their teachers. This is as a result of the competence and confidence the teacher exhibits in his teaching which is a reflection of their indepth knowledge of the contents of the subject. This implies that teachers must possess a deep understanding of the content of what they intend to teach. The perception by students that their teachers possess a deep understanding of the contents of mathematics topic they are teaching is capable of engendering confidence in the students. These students may start thinking that they could also study and know mathematics as their teachers, and that mathematics knowledge is not esoteric in any way.

Analysis of teachers' communication ability and students' attitude towards mathematics indicates a significant relationship. This finding is in line with the assertion of Afangideh (2001) who reported that any educational system depends to a large extent on the effectiveness of the communication system being adopted. And that no single subject can be learnt properly without communication; the use of its appropriate terms facilitates the understanding of whatever is being learnt. How successful any classroom interaction would be is determined by the competence of the teacher in initiating and promoting effective communication between and among his students. This implies that teachers should endeavor to make their speech and presentation unambiguous, coherent and logical for the students to understand and follow. Effective communication clears ambiguities, simplifies concepts and clarifies principles. This could lead to deep learning on the part of the students, and as students learn they develop a sense of achievement, satisfaction and growth. This would engender a more favorable students' disposition towards the subject matter learned.

The finding also indicates that the attitude of students towards mathematics learning is significantly related to how they perceive their teachers ability to employ appropriate instructional methods. The outcome of this finding is based on the fact that teachers who make use of different instructional methods in lesson delivery are likely to achieve a set goal, and the concept would be properly learned by the students. Esu (2003) opined that teaching by its nature requires a variety of methods and that the importance of having a variety of methods 
during a lesson delivery is to enable the teacher to carry every child along. Umoh (2005) calls for teachers to be systematic and methodical. Teachers of mathematics should have extra responsibility of being innovative, employing varieties in their instructional delivery to keep their students always alert and prepared to react positively and learn. When students feel or perceive that their teachers are adopting appropriate methods to teach them, they become more actively involved in the teaching/learning process. Learning is known to be an active process; the more the students are actively involved the more they learn, and the more they develop positive attitude towards what they learn.

Furthermore, data analysis indicates that the way students perceive their teachers' skills in classroom management relates significantly with their attitude towards mathematics. The outcome is based on the fact that when teachers provide conducive learning environment that is disciplined and orderly, it will promote positive learning attitude for the students. Udofot (1995) in an earlier study found out that a classroom serves as a theatre stage for learning, the prevailing control and discipline are strong determinants of successful learning and commensurate output. The nature of the lesson atmosphere depends on how the teacher teaches. When the teacher is firm and fair, he creates a better classroom climate with minimum tension and anxiety and the students are able to perform better. These climates lead to motivation, positive attitude and interest for mathematics.

The results of this study underscore the need for teachers to earn the confidence of their students through the display of deep knowledge of the subject matter they teach, good communication and effective instructional strategies and classroom management. These competencies promote students positive attitude towards their school subjects and hence academic achievements.

\section{Conclusion}

The result of this study indicates that teachers characteristics - knowledge of the contents to be taught, communication ability, ability to employ appropriate instructional strategies and competence in classroom management, relate significantly with students' attitude towards mathematics. Teachers' characteristics are positively correlated with students' attitude towards mathematics. When students' perception of their teachers' characteristics is low, it could result in their negative attitude towards mathematics and vice versa. Mathematics teachers should therefore strive to exhibit sound and effective pedagogical traits to earn their students' high perception. This will then engender students' positive attitude towards mathematics. As students' attitude improves, so will their commitment to the subject and their achievement will be enhanced.

\section{Recommendations}

On the basis of the findings of the study; it is recommended that:

1) Teachers of mathematics should periodically be given opportunities to update their knowledge through in-service training and retraining courses to increase their knowledge base in their subject area.

2) Teachers should adopt good communication techniques through verbal and non-verbal means that would attract students' attention and enhance effective communication during lesson.

3) More than one teaching method should be appropriately adopted in a single lesson presentation by a teacher so as to carry every student along, create variety, minimize boredom and enhance interest in what is being taught and learnt.

4) Teachers should create good classroom management strategies, to ensure democratic, disciplined and conducive atmosphere before and during every lesson.

\section{References}

Adediwura A. A., \& Tayo, B. (2007). Perception of teachers' knowledge, attitude and teaching skills as predictor of academic performance in Nigerian secondary school. Academic Journal on Educational Research and Review, 2(7), 165-171.

Afangideh, M. E. (2001). Communication in teaching learning process. In D. U. Umoren \& C. M. Ogbodo (2007), A handbook in teaching profession in Nigeria, 144-156. Uyo: Guidepost Publishers.

Ahmad, F. (2009). Students' perception of the teachers' teaching of literature communicating and understanding through the eyes of the audience. European Journal of social sciences, 7(3), 3-15.

Ajibade, Y. A. \& Ehindero, O. J. (2000). What our students say about how we teach. Ife Journal Education Studies, 7(1), 1-9.

Allport, G. W. (1968). Pattern and growth in personality. London, William Clowes and sons Ltd. 
Amoo, S. A., \& Rahman, M. A. (2004). Secondary school students' attitudes o learning mathematics in the world of information technology. Implication for mathematics teachers and teacher preparation. In Proceeding of the $42^{\text {nd }}$ Annual Conference of the Science Teachers Association of Nigeria, 178-182. Ibadan. Heinemann.

Ball, D. L., \& Bass, H. (2000). Interweaving content and pedagogy in teaching and learning to teach: Knowing and using mathematics. In J. Boaler (Ed), Multiple perspectives in mathematics of teaching and learning, 83-104. Westport, Conn: Ablex publishing.

Bryne, D. B., Hattie, D. A., \& Frazer, B. J. (2001). Students' perceptions of preferred classroom learning environment. Journal of Educational Research, 80(1), 10-16.

Eggen P., \& Kauchak, D. (2002). Strategies for teachers: Teaching content and thinking skills (4th ed.). In: A.A. Adediwura, \& B. Tayo (2007). Perception of teacher's knowledge, attitude and teaching skills as predictor of academic performance in Nigerian secondary schools. Educational Research and Review, 2(9), 165-171.

Esu, A. E. O. (2003). Teaching of social studies in primary school. In A. E. O. Esu \& E.P. Nkutidem (Eds.), Fundamental of Elementary Education. Calabar, Helino Associates.

Esu, A. E. O. (2004). Competences for effective teaching. In S.C. Uche \& I.O. Enukola (Eds), Professional skills for effective teaching. Aba: Aau Publishers.

Fennema, E., \& Franke, M. L. (1992). Teachers' knowledge and its impact. In: D. A. Grouws (Ed.) Handbook of research on mathematics teaching and learning. A project of the National Council of Teachers of Mathematics, 147-164. New York: Macmillan.

Gorton, R. A. (1983). School administration and supervision leadership: Challenges and opportunities. USA, Brown publishers limited. Retrieved March 4, 2011, from www.alibris.com/search/books/isbn/9780697062468

Huckstep, P., Rowland, T., \& Thwaites, A. (2003). Primary teachers' mathematics content knowledge, what does it look like in the classroom. Retrieved January 16, 2011, from www.Scribd.com/doc/22550939/journal

Isangedighi, A. J. (2007). Child psychology: Development and Education. Calabar: Eti-Nwa Associates.

Muijs, D., \& Reynolds, D. (2002). Teachers' belief and behaviours: What really matter? Journal of classroom, interaction, 37(2), 3-15.

Nworgu, B. G. (1990). Developing enhancing and sustaining interest in the teaching and learning of mathematics in primary schools. In B.G. Nworgu \& B. C. Ememgo (Eds.), The Nigerian Primary Education system. Trends, issues and strategies for improvement, 131-139. Onitsha: Etukokwu.

Obanya, P. A. I. (1984). General methods of Teaching. Lagos: Macmillan publishers Ltd.

Offorma, G. C. (1994). Curriculum implementation and instruction. Onitsha: Uniworld Educational publishers (Nig) Ltd.

Schunk, D. H. (1996). Learning Theories: An Educational perspective ( $2^{\text {nd }}$ ed). Englewood Cleffs N. J. Messill.

Udofot, M. A. (1995). Current trends of teacher Educational practices. Uyo: Imasons Educational services.

Umoh, M. U. (2005). Implementing social curriculum through pavlovian and Skinnerian learning strategies. Nigeria Journal for Curriculum Studies, 12(2), 32-36.

Umoren, D. N. (2001). The concept of education: Meaning and aims. In D. N. Umoren \& C.M. Ogbodo (2007), A handbook on teaching profession in Nigeria, 9-14. Uyo: Guidepost Publishers.

Uya, A. O. (2008). The effects of use of computer as teaching strategy on secondary school students' achievement in trigonometry in Oron Local Government Area. Unpublished project, University of Uyo, Akwa Ibom State.

Uya, A. O. (2011). Teacher's characteristics and students' attitude towards mathematics in senior secondary of Oron Federal constituency of Akwa Ibom State. Unpublished M.Ed Dissertation, University of Uyo. Akwa Ibom State. 